\title{
A tudomány a politika szolgálóleánya? (Adalékok) VOSZKA ÉVA
}

Az alkalmazott közgazdaságtan teóriáinak változásait a kuhni paradigmaelméletben elhelyezve több sajátosságot láthatunk. Egyfelöl a váltás a természettudományokra épitö modellhez viszonyitva kevésbé éles, a régi és az új hosszabb ideig is egymás mellett élhet, ső́t a visszafordulás sem kizárt. Másfelöl a változások fontos mozgatórugói nem annyira a tudományon belüli, mint inkább azon kivüli tényezök, döntöen társadalmi-gazdasági válságok - és ez teremt közvetlen kapcsolatot az elmélet és a politika között. A cikk a szakirodalom nagy részével egybehangzóan amellett érvel, hogy a kapcsolat nem egyirányú, nem szimpla megrendelö-szállitó viszony, hanem kölcsönhatás. De a teória nem számithat arra, hogy torzitásmentesen alkalmazzák: a politika a maga müködési szabályai szerint átformálja, felülírja az elméleti rendszereket. A politikai kereslet és a tudományos kinálat összehangolásának mechanizmusai ráadásul erös ösztönzést adnak arra, hogy az elmélet irányt mutató szerepe a legitimáló szerep felé forduljon, megteremtve a „korrumpált tudomány” közegét. Journal of Economic Literature (JEL) kód: B 20, R 61, H82.

A keynesizmus és a monetarizmus rég lezártnak hitt vitáját a 2008-as válság megint felélesztette. Ez a cikk a két nagy elméleti és gazdaságpolitikai irányzatot illusztrációként használva a tartalmi kérdések vitatása helyett azt vizsgálja, hogyan válik meghatározóvá az elméleten belül egy áramlat, és az milyen módon, milyen mértékben befolyásolja a politikát. E jórészt tudományszociológiai-politológiai témakör átfogó feltérképezésére nem vállalkozunk, csak néhány adalékot sorakoztatunk fel a köztulajdon változásának kutatása során szerzett tapasztalatok alapján. ${ }^{1}$

https://doi.org/10.47630/KULG.2017.61.5-6.8

Voszka Éva, Szegedi Tudományegyetem, Pénzügykutató Zrt. E-mail: voszka@yahoo.com

${ }^{1}$ A cikk egy készülő könyv fejezete alapján készült (Voszka, 2017). 
Az államosításhoz és a privatizációhoz kapcsolható elméletek és gazdaságpolitikai megközelítések - amelyek a cikk kiindulópontját adták - szorosan illeszkednek ugyanis a mindenkori föirányhoz, hiszen a fö választóvonal a tágabb és a szükebb terepen is az állam gazdasági szerepének felfogása. Az elemzés középpontjában azonban most az általános tudományos és gazdaságpolitikai keretek állnak, a tulajdonra vonatkozó megállapításokat csak példaként idézzük fel.

A cikk először az alkalmazott közgazdaságtan paradigmáinak sajátos vonásait mutatja be, majd a tudomány és a politika viszonyáról fogalmaz meg néhány hipotézist.

\section{A közgazdasági paradigmák sajátosságai}

Az uralkodó tudományos irányzatok és változásaik leírásához jó kiindulópont Thomas Kuhn paradigmafogalma. A közismert, eredetileg a természettudományokra építő elmélet szerint a tudomány nem egyenes vonalban, kumulatívan fejlődik, hanem „forradalmakon” keresztül.

A paradigma „Egyrészt a vélekedéseknek, értékeknek, módszereknek stb. egy adott tudományos közösség mindentagja által elfogadott összességét jelenti. Másrészt ...azokat a problémamegoldásokat, amelyeket modellként vagy példaként használnak, ...és így explicit szabályokat helyettesítenek" (Kuhn, 1962/2000, 179. o.). Az azonosan használt fogalmak, hasonló kérdések és módszertani megközelítések „természetes közege” rugalmas és biztonságos keretet ad a „normál tudomány” újításokra nem ösztönző „rejtvényfejtéséhez” - egészen addig, amíg el nem jön a paradigmaváltás ideje.

A változásnak lehetnek tudományon belüli és külső okai: új felfedezések, anomáliák - tények, jelenségek és összefüggések -, amelyekre az adott paradigma nem tud magyarázatot adni. Ez bizonytalanságot, majd válságot idéz elő. Sokasodnak a viták kérdésfeltevésekről, az alkalmazott módszerekről, egymással versengő iskolák jönnek létre, kommunikációs zavarok lépnek fel, mert a fogalmak jelentése átalakul. Végül győzedelmeskedik az új paradigma.

Ebbe a fogalmi rendszerbe a keynesizmus és a monetarizmus is beilleszthetö. Itt is jellemző, hogy az egyes elkülönült szakaszokon belül a kutatások túlnyomó többsége a fö irány igazolásával, újabb és jobb modellek kidolgozásával, az alapvető meggyőződést alátámasztó empirikus tapasztalatok gyüjtésével foglalkozik. ${ }^{2}$ Egy-

${ }^{2}$ Ez a munkák színvonalát nem minősíti, így dolgozik a mindenkori tudományos elit is (lásd: Colander-Holt-Rosser, 2004). 
egy korszak publikációinak zöme az éppen aktuális gyakorlati változásokat igazolja, a fóáram nyilvános kritikája ilyenkor szórványos.

A paradigmaváltásnak esetünkben is nyilvánvaló oka a válság, ami azonban az alkalmazott közgazdaságtan területén - az első sajátos vonásként - döntően külső eredetü: társadalmi-politikai-gazdasági válság, a keynesizmusnál az 1929-1933-as krach, a monetarizmusnál az 1970-es évek olajválságai. A tudományon kívüli krízishelyzet a tudományon belül is bizonytalanságot teremt: alapot ad a korábbi elmélet helytálló voltának kétségbe vonásához, megnyitja a lehetőséget az alaptételek vitatására, mert az uralkodó teória nem nyújt elfogadható magyarázatot a nehézségekre és nem tud választ adni az új kérdésekre. A fóáram védekezésre kényszerül, az „ortodoxia falanxa" (Hayek) gyengül.

„A külső sokkok és gazdasági krízisek megkérdőjelezik és destabilizálják az uralkodó ortodoxiát, amely nem tudta megakadályozni a válságot, vagy éppen annak az oka volt. Ahogy a domináns nézet gyengül, a »politikai vállalkozók« felhasználják a meglévő eszméket, vagy újra előhozzák a régebbieket, hogy alternatívákat ajánljanak a bukott ortodoxiával szemben" - foglalja össze több kutató nézetét Konzelmann [2011, 47. o.]. Felidézi Galbraith megállapítását is: a közgazdaság-tudományban a domináns nézetek alapvetően konzervatívak, és nem annyira az új elgondolások hatására változnak, hanem inkább „olyan körülmények erős támadásának következtében, amelyekkel nem tudnak megküzdeni” (i. m. 4.). Szintén a válság meghatározó szerepére utal Sylvia Nasar [2011], azt állítva, hogy a keynesizmust a stagfláció győzte le, nem egy rivális elmélet.

A gazdaságtörténeti elemzés azt mutatja, hogy az átfogó válságok nemcsak a köztulajdon terjedelmének, hanem az erre vonatkozó elméleteknek a változásában is fontos szerepet játszottak. A történet leegyszerüsítve a következőképpen foglalható össze. ${ }^{3}$ A 19. század végétől a háborúk idején, majd 1930-as években a magántulajdonra építő liberális paradigma nem tudta kielégítően kezelni sem a társadalmi feszültségeket, sem a meg-megújuló gazdasági kríziseket, sőt sokan a bajok kiváltó okának, a hibás, a nehézségeket csak tetéző gazdaságpolitikai válaszok előidézőjének tekintették azt. Egymás után jelentkeztek olyan versengő elméletek, először a különféle szocialista-szociáldemokrata irányzatok, majd a keynesi eszmék, amelyek megváltoztatták a célok hierarchiáját és az alkalmazható eszközrendszert is. Az új törekvéseknek - a társadalmi egyenlötlenség, illetve a munkanélküliség mérséklésének - fontos módszere lett a köztulajdon kiterjesztése, vagy ez legalábbis be-

\footnotetext{
${ }^{3}$ Lásd részletesen: Voszka [2017].
} 
illeszthető volt az új megközelítésbe. A „keynesi forradalom” az állami tulajdon felfogásában nem hozott paradigmaváltást, mert ebben a kérdésben nem tért el gyökeresen a megelőző, a demokratikus keretek között maradó szocialista elgondolások különböző változataitól.

Az 1970-es években az állam erős gazdasági szerepét, ezen belül a tulajdonlás további bővítését pártoló nézetek azért kerültek defenzívába, mert tekintélyüket megtépázta a változatlanul erre a paradigmára épító válságkezelés kudarca. Az ellenfeleknek nem volt nehéz az egyéni szabadság és a hatékonyság jegyében a neoliberális megoldások, köztük a privatizáció mellett érvelni. A 2008-as válság egy kérészéletű, kiterjedt államosításokba torkolló keynesi konszenzushoz vezetett, de az elméleti egyetértés hiánya tartósnak látszik, noha igény volna egy új paradigma (vagy új szintézis, esetleg konzervatív fordulat) létrehozására. ${ }^{4}$ Felfogásunk szerint az állami szerep értékelésének - vagyis az alapparadigmának - az elbizonytalanodása az alapvető oka annak, hogy köztulajdon-paradigma korábban egy-egy szakaszban azonos irányú változása széttöredezett: az államosítási és privatizációs hullám az utóbbi években gyorsan váltotta egymást, illetve éveken keresztül párhuzamosan jelentek meg (Voszka, 2016).

A társadalmi-gazdasági válság meghatározó szerepe mellett a közgazdasági paradigmák változásának másik sajátos vonása tehát, hogy a természettudományokban példátlan módon a korábbi elméletek újra uralkodó pozícióba is kerülhetnek - jó okot adva azok megőrzésére a legyőzetés után is. Ez pedig, harmadszor, hozzájárul ahhoz, hogy a különböző nézetrendszerek tartósan egymás mellett élnek, a váltás kevésbé éles. Végül, az alkalmazott közgazdaságtan teóriáinak létrejöttében és sorsuk alakításában fontos szerepet játszik a politika. A két utóbbi állítás mellett érvelnek a következő fejezetek.

\section{Elfogadtatás a tudományon belül}

A paradigmák változásával kapcsolatban kézenfekvő kérdés, hogyan lehet elfogadtatni az új nézeteket a tudományos közösséggel, ha a „rombolva építő változás” (Kuhn) a megszokott nézőpontok, módszerek feladását igényli, és a kutatók alapvetően konzervatívak, mint ahogy azt Galbraith is állítja? Ezt a vaskalaposságot többen vitatják. Colander, Holt és Rosser [2004] például a szociológiai kategóriának tartott mainstream és az intellektuális fogalomkörbe sorolt ortodoxia megkülönböz-

${ }^{4}$ Az egyetértés okairól és gyors felbomlásáról lásd Farrell-Quiggin [2012]. Az új paradigma szükségességének indokait részletesen kifejti: Csaba [2014]. 
tetésével a főáramhoz kötődő elit egy részének nyitottságát hangsúlyozza. Úgy látják, hogy a szakma mindig is sokdimenziós; egymással versengő - de nem azonos befolyással rendelkező - iskolákból áll. ${ }^{5}$ Az új ötletek, megközelítések a közgazdaság-tudományban folyamatosan és nem eredménytelenül ostromolják az uralkodó irányzatot, sok elemük beépül a régi keretekbe, fokozatosan alakítva azokat. Azaz a változás nem törésszerü, inkább kumulatív folyamatokról van szó - bár, állítják, minél alapvetőbb a változás, annál inkább a kuhni paradigma érvényesül.

Gyakran előfordul, hogy az új irányzat nem söpri el, csak háttérbe szorítja elődjét, ami azonban látens módon tartósan fennmarad. Ezt példázza Mises és Hayek évtizedeken keresztül kisebbségben lévő, és csak azután győzedelmeskedő felfogása, valamint Keynes esete is: „Még ha a keynesizmusról folytatott vita halottnak látszott is - írja az 1980-as évek közepének helyzetéröl Farrell és Quiggin [2012, 16. o.] -, és kevés jeles közgazdász publikált olyan írásokat, amelyek közvetlenül keynesi megoldásokat ajánlottak volna, jelentős keynesianus párt rejtőzködött az akadémiai tudomány köreiben.” Az új keret esetenként magába épitette, felszívta a rivális elméletet, ahogy a szociáldemokrácia a liberalizmus elemeit, majd a jóléti teóriák a szociáldemokrata értékek jelentős részét, beleértve a tulajdonra vonatkozó nézeteket is. A korábbi megközelítés hívei sokáig utóvédharcokat folytattak az állami vállalatok és részben a privatizáció esetében is. Azok a társaságok, intézmények, folyóiratok, műhelyek, amelyek egy-egy elmélet aranykorában kialakultak, gyakran tovább müködnek, életben tartva témáikat és eszméiket.

Ami az új paradigma tudományon belüli térhódítását illeti, ezt Farrell és Quiggin [2012] a ,fertőzés" fogalmával írja le, amely a nemzetközi közösség személyesszakmai kapcsolatokból épített hálózatain keresztül, tanulás, utánzás és kommunikáció révén terjed. Ebben a neves „sztárközgazdászok” központi szerepet játszanak. Minden elemző alapvetőnek tartja a tudomány intézményrendszerének hatását, a hierarchizált és szegmentált közlési fórumoknak, a szakmai közönségnél szélesebb nyilvánosságot is elérő írott és elektronikus sajtónak, valamint az oktatás különböző szintjeinek meghódítását.

Az oktatás azért is fontos, mert az elfogadtatás többnyire hosszadalmas folyamat, ${ }^{6}$ a teljes paradigmaváltás sokszor generációváltást feltételez. Új tanköny-

5 Csaba László az ezredfordulón [1999, 5. o.] egyenesen „száz virág virágzásáról” beszél „mind iskolák, mind szellemi irányzatok, mind a módszertani jellemzők tekintetében”. Később sajátos ellentmondásként regisztrálja, hogy miközben bár a fóáramot egyre hevesebb támadások érik, annak uralma a tudomány legfontosabb intézményeiben töretlen, sőt még erősödik is" (Csaba, 2014).

${ }^{6}$ Kivétel a 2008-as gyors - de időleges - váltás. E a sajátos helyzet értelmezésére még visszatérünk. 
vekből tanuló új nemzedéknek kell felnőnie, amely már a megváltozott keretet tekinti „természetes közegének”. A szó hétköznapi értelmében vett meggyőzés ugyanis kevéssé müködik. „A szembenálló felek vitája ...többé-kevésbé menthetetlenül süketek párbeszéde... A paradigmák közötti verseny bizonyítékokkal eldönthetetlen" - állítja Kuhn [1962/2000, 154. o.], ${ }^{8}$ részben azért, mert a normák összemérhetetlenek. Nemcsak vitapartnereink, hanem mi magunk is régi hiteink, meggyőződéseink és módszereink foglyai vagyunk. ${ }^{9}$

Az állitás az államosítási-privatizációs elméletekkel is jól szemléltethető. Az ellentétes nézetek elfogadására ebben a körben nem találtunk példát - legfeljebb a saját elmélet korrekciójára (a gazdaságpolitikában és az állami tulajdon felfogásában is „revizionista” Lenin), ${ }^{10}$ beletörődésre, háttérbe húzódásra (Hayek), vagy az álláspont finomítására, részleges önkritikára (néhány világbanki szakértő esetében). Egy-egy látványos áttérésre nem itt, hanem az állam szerepének általánosabb kérdéskörével kapcsolatban került sor a 2008-as válság sokkjának hatására (Posner, 2009).

Mivel a gazdasági elméleteknek ez az ága közvetlenül az aktuális gazdasági folyamatokra reagál, és sokszor nem titkoltan a (gazdaság)politikát próbálja befolyásolni, a politikának az éppen adott helyzetből adódó igényei és specifikus lehetőségei a paradigma kidolgozásában és annak a tudományon belüli elfogadtatásában fontos katalizátorok. Sőt, az is előfordul, hogy az utóbbira nincs is szükség a gyözelemhez. Az 1970-es-1980-as évek fordulóján Friedmannak kevés követője volt az angol elméleti-egyetemi körökben - sőt a legfelső szint kivételével a kormányzati adminisztrációban is -, írja Nelson [2009]. Ezt Hall elemzése is megerősíti: „...a monetarizmus nagyon kevés támogatást kapott a brit közgazdászoktól, akik túlnyomórészt keynesiánusok maradtak. Ez nem olyan eset volt, amelyben a szakértői vélemények többsége megváltozott, maga után húzva a politikai döntéshozókat. Ehelyett politikai, nem pedig tisztán gazdasági kritériumok váltak a monetarista paradigma győzelmének kulcstényezőivé" (Hall, 1993, 286. o.).

7 ,...az állambölcselet és a közgazdaság-tudomány terén ... kevesen müködnek olyanok, akiket a huszonötödik vagy harmincadik életévük betöltése után új elméletek befolyásolnak" - írja Keynes [1936/1965, 408. o.], talán nem irónia nélkül.

${ }^{8}$ Ha a paradigmaelmélettel egyébként vitázó Karl Popper felfogását követjük, akkor ez nemcsak a paradigmákra, hanem minden tudományos állításra igaz: ezeket bizonyítani nem, csak cáfolni lehet.

${ }^{9}$ Ez részben pszichológiai tényezőkkel magyarázható, a Kahneman [2013] által leírt „gyors” (mintegy automatikus, energiatakarékos) és „lassú” (megfontolást, erőfeszítést igénylö) gondolkodás közötti különbségtétellel. Erre utal Galbraith is: „A gazdasági és a társadalmi magatartás komplex, mentálisan fárasztó. Ezért kapaszkodunk azokba az eszmékbe, mint egy tutajba, amelyek kifejezik nézeteinket (idézi: Yarrow, 2014, 9. o.).

${ }^{10}$ Lásd erröl részletesen: Schlett [2017]. 
Kérdés, hogy vannak-e másféle esetek, vagyis játszanak-e az elméletek kezdeményező és meghatározó szerepet a politika alakításában? S ha próbálkozik ezzel a tudomány, akkor milyen módszereket alkalmaz?

\section{Az eszmék hatalma és korlátaik}

A gazdaságpolitika és a tudomány kapcsolatáról megfogalmazott nézetek skálájának egyik végpontján az elméletek meghatározó szerepe áll. Keynes az Általános elmélet gyakran idézett záró soraiban egyértelmủen fogalmaz:

„...a közgazdászok és a politikai filozófusok nézetei - akár igazuk van, akár tévednek - sokkal nagyobb hatásúak, mint rendszerint hisszük; valójában mindennél jobban hatnak világunk sorsára. Azok a gyakorlati emberek, akik teljesen mentesnek vélik magukat minden szellemi befolyás hatásától, rendszerint valamelyik rég elhunyt közgazdász rabszolgái. Magas állásokat betöltő őrültek, akik hangokat hallanak a levegöben, hajdani könyvmolyoktól kölcsönözték rögeszméik magvát... Elöbb vagy utóbb azonban az eszmék és nem a hagyományos érdekek törnek új utakat, és vezetnek jóra vagy rosszra" (Keynes, 1936/1965, 408. o.). De ehhez olyan körülmények is kellenek, amilyenek a könyv írása idején éppen adottak voltak: „Az emberek ma különösen türelmetlenül várnak a szokásosnál alaposabb diagnózisra” - írja Keynes 1936-ban. „Buzgón készülnek a kipróbálására, ha legalább hihetőnek tủnik" (uo. 407. o.). Vagyis az elhúzódó válság felkelti a közvélemény - és tegyük hozzá, ezzel együtt a politikusok igényét az új elméletekre, megnöveli a fogadókészséget.

Ez a felfogás nem feltétlenül ellentétes az elöbbi idézetben szereplö helyzetértékeléssel, amely szerint a politika befolyásolásához nincs okvetlenül szükség a szakmán belüli egyetértésre, mert az „eszme” itt még nem a szakma többségi véleménye, hanem az éppen megjelenő új paradigma, amelynek tudományos elfogadtatásához Keynes szerint is hosszú idő kell, politikai elfogadtatásához pedig válsághelyzet. Ez utóbbi szempontot hangsúlyozza Friedman [1962/2002, xiv. o.] is: „Csak egy folyamatban lévő vagy fenyegető válság vezet valódi változáshoz. Amikor a válság megjelenik, a meghozott intézkedések azoktól az eszméktől függenek, amelyek éppen elérhetők. Ez az alapvető feladatunk: alternatívákat kidolgozni a létező politikákkal szemben, életben tartani és elérhetővé tenni őket addig, amíg a politikailag lehetetlen politikailag elkerülhetetlenné válik." 
Keynes és Friedman idézett nézetei a válság középponti szerepéről egybevágnak az újabb keletủ felfogással, amely a politikusok tanácstalanságát, egy talány megoldásának kényszerét emelik ki. Ennek az álláspontnak a képviselői „...azt hangsúlyoznák, hogyan találták szembe magukat a politikai döntéshozók rendkívüli bizonytalansággal és a közvélemény erős igényével arra, hogy tegyenek valamit” az összeomlás elkerülése érdekében - írja Farrell és Quiggin [2012, 6. o.] a 2008-as válság kezelése kapcsán. E felfogás alapkategóriája, a „töprengés”"11 Hugo Heclótól származik: „A politika nemcsak a hatalomból merít erőt, hanem a bizonytalanságból is - amikor az emberek kollektíven tűnődnek azon, hogy mit tegyenek... A kormányok nemcsak »hatalmat gyakorolnak«, hanem »töprengenek is« - ami a politika által kifejezésre juttatott társadalmi tanulás egyik formája (idézi: Hall, 1993, 275. o.). Ez az a fázis, amikor az „elérhető” eszmék valóban erős befolyást gyakorolhatnak. Legalábbis az egyik közülük, amelyiket a politika zászlajára tűz, az elfogadottság tekintélyével ruház fel.

A 20. századi gazdasági paradigmák két kulcsszereplőjének az előbb citált véleménye közötti különbség éppen ebböl következik: Keynes jó pillanatban szólalt meg, Friedman viszont nem véletlenül emelte ki az elmélet életben tartásának fontosságát - neki még évtizedeket kellett várnia a gyakorlati befolyás megszerzésére. Álláspontjuk lényege azonban egybecseng. Az elméletek fontosak, de dönteni a politikusok döntenek, amikor egy válság hatására, az elbizonytalanodás körülményei között valamit tenniük kell: töprengenek, körülnéznek, és választanak a „levegőben lévö", készen talált alternatívák közül - amelyek kidolgozói, ha nincs szerencséjük, már régen halottak.

A szerencsések közé tartozó Hayek példája alátámasztja az elméletek szerepének ezt a felfogását, de egyben megmutatja a korlátokat is.

Hayek közvetlen befolyást gyakorolt a brit gazdaságpolitikára. „John Ranelagh meséli azt az anekdotát, hogy az 1970-es években a konzervatív párt ülésén Margaret Thatcher előhúzta a ridiküljéböl Hayek könyvét, »A szabadság alkotmányá«-t. Fölmutatta a szónoknak, aki éppen a jobb és bal közötti pragmatikus középút mellett érvelt, és azt mondta: Ez az, amiben mi hiszünk" (idézi: Konzelman, 2011, 5. o.). A Thatcher Alapítvány közel másfélszáz dokumentumot közöl a neves tudós, valamint a miniszterelnök és közeli munkatársai közötti kapcsolatról, amelyek zöme személyes levél. ${ }^{12}$ Egy 1982. február 17-én kelt írás arra a tanácsá-

11 Az angol puzzling szó egyszerre fejezi ki a tanácstalanságot, a tépelődést és a rejtvény megfejtését, amit fordításunk szegényesen ad vissza.

${ }^{12}$ Lásd: http://www.margaretthatcher.org/archive/Hayek.asp 
ra adott válasz, amelyben Hayek a chilei példát, föként a költségvetési kiadások radikális csökkentését javasolja. „Biztos vagyok benne - szól az udvarias riposzt -, hogy egyetért velem: Nagy-Britanniában a mi demokratikus intézményrendszerünkkel és az egyetértés magas fokának igénye mellett néhány Chilében alkalmazott intézkedés teljesen elfogadhatatlan volna. Reformjainknak összhangban kell lenniük hagyományainkkal és alkotmányunkkal. Néha úgy tünhet, hogy a folyamat fájdalmasan lassú. De meg vagyok győződve, hogy reformjainkat meg fogjuk valósítani a saját magunk útján és a magunk időzitése szerint. Akkor tartósak maradnak."13

Ez a példa is utal arra, hogy a nagy elméleti paradigmákat a gyakorlati gazdaságpolitika sehol sem követte a maguk eredeti formájában. A Keynesre hivatkozó rendszerek az állami költekezést, a deficitfinanszírozást nemcsak válsághelyzetben, hanem „békeidőben” is alkalmazták, és a teóriában nem szereplő területekre (szociálpolitika, állami tulajdon) is kiterjeszkedtek. A friedmani monetarizmusnak pedig olyan alapvető elemei nem valósultak meg, mint a jegybank önálló döntési jogkörének helyettesítése a pénzmennyiség automatikus változásával, vagy egyáltalán a pénzmennyiség szabályozásának centrális szerepe. ${ }^{14}$

A hivatalban lévő politikus tehát saját szempontjai és körülményei szerint értékeli az elméleti javaslatokat és a máshol már megvalósított példák tanulságait. ${ }^{15}$ A sajátos szempontokat pedig sok tényező alakítja. Keynes Ricardóról írta, ami rá magára és Friedmanra is vonatkoztatható: „Teljes győzelmében van valami rendkívüli és misztikus. A diadal valószínüleg annak köszönhetö, hogy az elmélet komplex módon megfelelt annak a környezetnek, amelyre rávetítették" (idézi: J. Galbraith, 2008, 3. o.). Másként fogalmazva, a teóriáknak nem önmaguktól/önmagukban van erejük, mint arra már John Stuart Mill is felhívta a figyelmet. „Az eszméknek, hacsak a külső körülmények nem kedveznek nekik, általában nincs nagyon gyors vagy közvetlen hatásuk" (idézi: Hall, 1989b, 390. o.).

${ }^{13}$ Kiemelés nem az eredetiben. Lásd: http://fc95d419f4478b3b6e5f-3f71d0fe2b653c4f00f32175760e96e7.r87.cf1.rackcdn.com/3D5798D9C38443C6BD10B1AB166D3CBF.pdf

${ }^{14}$ Az utóbbit az Egyesült Államokban az 1970-es évek végén rövid ideig alkalmazták ugyan, de James Galbraith [2008, 5. o.] szerint „Az eredmény katasztrofális volt... 1982 augusztusában a Fed szakított a monetáris célkitűzés rendszerével, és soha nem tért vissza hozzá... Ami ezután megmaradt (a monetarizmusból), az egy sor doktrína volt.” Friedman elveit a 2008-as válságkezelés második szakaszában is korlátozottan alkalmazták, lásd: Nelson [2011].

${ }^{15}$ Ez lehet az egyik választóvonal a kapitalizmus különbözö változatai között, még a homogénnek tekintett országcsoportokon belül is, mint azt Konzelman [2001] az angolszászok közötti eltérésekröl állítja: Ausztrália és Kanada kiegyensúlyozottabb liberalizmust követett, mint a „neoklasszikus” Nagy-Britannia és Egyesült Államok, ami a válságok mélységére és kezelésére is kihat. 
A teória megfelelése a környezetnek olyan elemeket jelenthet, mint - ahogy az Általános elmélet is utal rá - a válság keltette igény az új magyarázatra és megoldásra, mégpedig a központi probléma megoldására (ami az 1930-as években a munkanélküliség, négy évtizeddel később az infláció, illetve a stagfláció). A fejezet elején idézett passzusok azt is mutatják, hogy Keynes, miközben az eszmék meghatározó szerepe mellett érvel, hallgatólagosan elutasítja az érdekek perdöntő hatását. Feltehetően még inkább tiltakozott volna az ellen, hogy elmélete figyelembe venné az erős gazdasági csoportok törekvéseit. Az intézményi közgazdaságtan több elemzése azt mutatta, hogy az eszmék befolyása nagymértékben függ a politikai pártok, a szakszervezetek, az üzleti szereplök, valamint a politikai és értelmiségi elit támogatásától.${ }^{16}$ Kevésbé elfogulatlan elemzések viszont bírálják a paradigmák megalkotóit azért, hogy elméletük megfelelt bizonyos érdekeknek.

Nelson $[2009,468$. o.) szerint Keynes sikerének titka az, hogy „...elfogadható elméleti keretet adott a nagy léptékủ kormányzati beavatkozáshoz, ...nagyon is megfelelt a piaci rendszer ellenzöinek". James Galbraith [2008, 3. o.] pedig Friedmant bíráló cikkében azt állítja, hogy a monetarizmus atyja „....azért diadalmaskodott, mert munkája elég komplex volt ahhoz, hogy tudományos eredményként jelenhessen meg, és mert elgondolásai megfeleltek egy meghatározott kör prekoncepcióinak" (uo.). Keynes esetében a munkaadók alacsony kamatokat, a kereslet növekedését várták, a munkavállalók a foglalkoztatás, a jövedelem emelkedését; a monetarizmusnál pedig az előbbiek a kiszámíthatóság javulását, az áremelkedések és a kamatok folyamatos csökkenését, az utóbbiak a bérek értékállóságának megteremtését, majd gyarapodását. Részben ezen keresztül mindkét elmélet összevág a politika érdekeivel is: javítja az újraválasztás esélyét, mert stabilizálja a gazdaságot, enyhíti a társadalmi konfliktusokat.

A válság teremtette fogadókészség és az erős gazdasági érdekek érvényesítése mellett ez az utóbbi szempont, a közhangulat, a közvélemény megnyerése is fontos. Ezt hangsúlyozza John Campbell is, a politikát formáló eszméknek négy típusát különítve el, amelyeknek egyike - de önmagában nem meghatározó eleme - a tudományos elitek által kidolgozott paradigma.

„Az eszmék specifikus megoldásokat kínálnak politikai problémákra, kijelölik a megoldásoknak azt a kognitív és normatív terét, amelyet a politikai szereplök figyelembe vesznek, továbbá olyan szimbólumokat és fogalmakat alkotnak, amelyek lehetővé teszik a szereplők számára a politikai javaslatok legitimálásá-

${ }^{16}$ Lásd például a Peter Hall [1989a] szerkesztette kötet tanulmányait, illetve értékelésként John Campbell [1997] írását. 
hoz szükséges keretek összeállítását" (Campbell, 1997, 20. o.). A kognitív szint a program és a paradigma, a normatív pedig a közhangulat és a legitimáló keret. Egy eszme hatása akkor a legnagyobb - demonstrálja a szerző a reagani gazdaságpolitika kialakulásának példáján -, ha világos és egyszerủ megoldást ad az aktuális problémára, megfelel az elméleti paradigmának és a közvéleménynek is - ezt pedig a társadalmilag elfogadható megfogalmazás („tálalás”) nagymértékben elösegítheti.

A politika mindezen tényezők befolyása alatt szelektál, értelmez, méretre szab ha teheti. Kevésbé szerencsés országok, mint a fejlődő világ és Kelet-Közép-Európa államai jobban rákényszerülnek arra, hogy külső hatásokat is figyelembe vegyenek, nemzetközi tanácsadók és szervezetek ajánlásait kövessék. De még ilyenkor sem egyforma a megközelítés. Csaba László már az 1990-es évek közepén úgy látta, hogy az átalakuló országokban ,,a megoldások tartós sokszínűsége” jellemző: „Miközben a sugallat vélhetően mindenütt a »washingtoni konszenzus« volt, az eredmény szélsőségesen szóródik - ez pedig a belső mérlegelés túlsúlyának bizonyítéka" (Csaba, 1995, 124., kiemelés az eredetiben). A sokszínüséget, a kelet-közép-európai kapitalizmusmodellek változatosságát mutatja be az ezredforduló után Bohle-Greskovits [2012] is. ${ }^{17}$

A politikusok mozgásterét bővíti, ha többféle elmélet van jelen a porondon. „.... szakértők elgondolásai ${ }^{18}$ nagyobb valószínüséggel formálják a politikai végeredményt, ha látszólagos egyetértésre támaszkodhatnak. Ha viszont véleményeltérés van a fontos szakértői közösségen belül, és ahol ez a véleményeltérés nagyjából leképezi a különböző politikai szereplők által előnyben részesített különböző cselekvési irányokat, akkor a politikai döntéshozóknak nagyobb mozgásterük van. Mivel nincsenek korlátozva a szakma konszenzusa által, azt a szakmai csoportot választhatják, amelyik számukra a leginkább alkalmasnak látszik... Ilyen körülmények között a szakértők szerepe nem az, hogy a vitát alakítsák, hanem hogy legitimációt adjanak" - írja Farrell és Quiggin [2012, 10. o.].

A szerzők a 2008-as válságot követő éveket vizsgálják, ami azonban sajátos abból a szempontból, hogy itt nem egy letünt és egy vadonatúj, hanem két korábbi

${ }^{17}$ Korábbi időszakra vonatkozó alapos elemzések azt is kimutatták, hogy egy-egy paradigmát a fejlett országok körében sem azonos módon és mértékben alkalmaztak. A keynesi gazdaságpolitika elterjedtségét összehasonlító módszerekkel vizsgáló tanulmánykötet meggyőzően demonstrálja a konkrét történelmi, politikai és intézményi feltételek szerepét az eltérések magyarázatában (Hall, 1989a).

18 A cikk egésze alapján világos, hogy ebbe a szerzők a tudományos paradigmákat is beleértik. A „látszólagos egyetértés” azt jelenti, hogy a fö irányt a tekintélyes szereplők nyilvánosan nem kérdőjelezik meg. 
paradigma vetélkedett egymással, amelyek mindegyikének volt - ha nem is egyenlö erejü - intellektuális-intézményi háttere. A kész, a siker reményével kecsegtető, ámbár régi teóriát egyszerủen elő lehetett húzni, amikor a döntéshozók az azonnali öszszeomlástól féltek. A két előző paradigmaváltásnál viszont nagyobb volt a különbség a szembenálló felek között: a korábbi megközelítés a szakmán belül még többséget alkotott, de éppen az aktuális válság miatt nehéz volt védelmezni, míg az új, még nem bevett eszmerendszer ígéretesnek látszott, viszont az elfogadtatás időigénye miatt a tudományban még nem jutott domináns helyzetbe. A paradigmaváltások természetéből következően ezért úgy vélem, hogy a szakmai konszenzus nem tekinthető általában az elfogadtatás nélkülözhetetlen feltételének.

Annyit mindenesetre állíthatunk, hogy az elmélet - az előbb vázolt egyéb tényezőkkel együtt - valóban befolyásolhatja a gazdaságpolitikát. Fontos azonban hangsúlyozni, hogy a hatás nem egyirányú: a helyzet, a korszellem és a maga kérdéseivel, igényeivel a politika is inspiráló, meghatározott célok felé tereli az elméletalkotást. A tudomány is abból indul ki, ami „a levegőben van”.

Az állítás legjobban Keynes példájával illusztrálható, akinek elmélete Galbraith [1988] szerint az új gazdaságpolitikai programoknak nem kiindulópontja volt, hanem „kikristályosodási pont”-ja. Teóriájának az a magja, amely a rá hivatkozó rendszerek legfontosabb eleme lett - állami keresletélénkítés a munkanélküliség leküzdésére -, jóval az alapmű megjelenése előtt felbukkant az elméletekben, sőt a gyakorlatban is megvalósult. Ernst Wigforss, a svéd szociáldemokrácia egyik legbefolyásosabb teoretikusa már az 1920-as években hasonló lépéseket javasolt, és Svédország a nagy válság kezdetétől alkalmazta is a módszert. Az amerikai New Deal indítása évekkel megelőzte az Általános elmélet megjelenését. Igaz, hogy a szerző korábban is megfogalmazta és a széles nyilvánosság elött képviselte is nézeteit. Már az 1920-as években állami aktivitást, közmunkaprogramokat javasolt, a laissez faire-rendszer kudarcairól beszélt. Amikor 1932 októberében a tekintélyes The Times vitát indított a magán- és állami költekezésröl, a rövid hozzászólásokban nemcsak Hayek, hanem Keynes is akkor már jól ismert álláspontját hangoztatta ${ }^{19}$ - de ebből is látszik, hogy az alapmü megírását, a részletes, összefogott kifejtést a krízis és az általa keltett társadalmi-politikai kereslet ösztökélhette.

Hasonló jelenséget a köztulajdon változásának szűkebb területén is megfigyeltünk, sőt itt inkább ez látszik föszabálynak. Az államosítások esetében, legalább-

19 Lásd: https://www.researchgate.net/publication/294543091_Private_spending_money_for_ productive_investment_a_comment_by_economists_to_the_editor_of_the_Times 
is a 19-20. század fordulóján még lehetett korábban kidolgozott, koherens elvekre támaszkodni, ha ezek a gyakorlati megvalósításhoz kevés támpontot adtak is. Az első világháborút követő lépésekhez azonban a töredezett elmélet általános keretként nem volt „elérhető”, és semmiképp sem lett perdöntő hivatkozási alap a politika számára. A privatizációnak olyan elvi alátámasztása pedig, amelyik túllépett a magántulajdon és a piac általános pártolásán, egyértelmúen csak utólag jelent meg, amikor a folyamat már javában zajlott. A gyakorlat teremtett igényt az elméleti igazolásra, nem pedig a tudomány kínált fel lehetséges alternatívát a politikának. ${ }^{20}$ Vagyis Farrell-Quiggin [2012] előbb idézett kategóriarendszerében ezek a teóriák nem irányt mutattak, hanem legitimáltak.

Az elméletek megalkotói azonban még ezekben a számukra kényelmesnek tekinthető helyzetekben sem tétlenek. „Nem az én dolgom, hogy meggyőzzek embereket különböző dolgokról. Csak kidolgozom az elképzeléseket, és otthagyom őket az embereknek, hogy használják őket" - állította egy interjúban Milton Friedman (idézi: Nelson, 2009, 494. o.). Ez a legjobb esetben is eufemizmus. Sok közgazdász, élükön a 20. század nagy paradigmáinak kidolgozóival, ugyancsak aktívan próbálta elfogadtatni nézeteit nemcsak a tudományos közösséggel, hanem a politikával és a szélesebb közvéleménnyel is. Ennek során új szerepekbe léptek át, vagy szerepváltásokra is sor került.

\section{A politikai elfogadtatás módszerei}

Nemcsak a szakma, hanem a közvélemény és a gazdaságpolitika befolyásolásának is egyik alapvető módszere a nyilvánosság fórumainak használata az írott sajtó publicisztikáitól a televíziós fellépésekig, majd az egyre népszerủbb blogokig.

A svéd közgazdászok hagyományosan fontos résztvevői a nyilvános vitáknak. Neves teoretikusaik közül Gustav Cassel mintegy 1500, Knut Wicksell 450 cikket írt napilapokba, mindketten küldetésüknek tekintették a „népnevelést”, a közvélemény felvilágosítását és befolyásolását (Carlson-Jonung, 2006). Mindkettőjüket nagyszerủ debattőrnek tartották, csakúgy, mint később Keynest és Friedmant. Az utóbbiak is ,....kiváló vitázók voltak, akik a gyakorlati politikai kérdésekre összpontosítottak. Mindkettőjüket ideológiai megfontolások vezérelték" - írja Craig Freedman [2006, 99. o.). Keynes a Times cikksorozataiban és a $\mathrm{BBC}$ rádióadásaiban népszerűsítette nézeteit. A „nagy rábeszélő” [Skidelsky,

20 Lásd részletesen: Voszka [2017]. 
2009] ezt a képességét az egyetemen, az újságokban és a politikusok dolgozószobáiban is csillogtatta. Friedmant és nézeteit a legszélesebb körben ismertté tette az a tízrészes tévésorozat, amely a Választhatsz szabadon címú könyve alapján készült. Az angol kifejezés jól leírja ezt a társadalmi funkciót: public intellectual. Az ilyen közszereplők „politikai vállalkozók” - sztárok, nemcsak a média, hanem a szakma közismert képviselöi, akiknek középponti pozíciójuk van a tudományos élet hálózataiban - és így az új eszmék „fertőzésének” terjesztésében - is (Farrell-Quiggin, 2012).

Ha a közvéleményt és a politikát a piac valamilyen formájának tekintjük, akkor a meggyőzést marketingnek is lehet nevezni. „A marketing egyszerüen azt jelenti, hogy egy elmélet jobban kielégíti a piaci keresletet, mint a rivális teóriák. Ez még semmit sem mond az adott elmélet helyességéről vagy igazságáról... A marketing, azaz annak a tudása, hogyan lehet elöre látni a szakma igényeit, legalább olyan fontos, mint maguk az előadott teóriák" (Freedman, 2006, 91., 99. o.). Válsághelyzetekben a közgazdasági eszmék piaca rendkívüli módon kiterjed, beleértve új kutatóintézetek létrehozását és azt, hogy „....a sajtóban megjelenő gazdasági kommentárok addig is nagy száma tovább nőtt, és az érvelések még kifinomultabbá váltak" - írja Hall [1993, 286. o.] az 1970-es évek Angliájáról. Úgy látja, hogy az új (itt: monetarista) paradigma áttörésében - a pénzügyi szereplők nyomása és a parlamenti választások eredménye mellett - a média is föszerepet játszott.

A közszereplés az elméleti emberek ismertségét és elismertségét, tekintélyét növeli - nemcsak a szakmán belül, hanem a politika világában is. A döntéshozókra gyakorolt hatásnak azonban van közvetlenebb módja, a kinevezéshez vagy eseti felkérésekhez kötött, esetleg informális-személyes tanácsadás. Erre az általunk vizsgált kör is számos példát mutat.

Említettük már Hayek és Margaret Thatcher levelezését és szívélyes személyes kapcsolatát. De a brit miniszterelnök Hayek gazdaságfilozófiáját tartotta nagyra, politikáját inkább Milton Friedman befolyásolta. „Ha akkoriban Hayek volt a nyájas filozófuskirály, Friedman volt a frenetikus gyakorlati ember, aki a színháztermekben tartott előadásokról elnöki lakosztályokba repült, mindenhol megjelent az újságok legolvasottabb oldalán és a tévé képernyőjén... Míg Margaret Thatcher Hayekkel négyszemközt folytatott csendes beszélgetéseket, Friedmant és feleségét, Rose-t a miniszterek küldöttsége fogadta" - de a kormányzat az ő javaslatait sem fogadta el maradéktalanul. ${ }^{21}$ Friedman az Egye-

${ }^{21}$ Lásd: http://www.margaretthatcher.org/archive/Hayek.asp 
sült Államok több elnökének is tanácsadója volt. Korábban Keynes személyes kapcsolatban állt Roosevelt elnökkel, hazájában pedig közremüködött tanácsadóként, parlamenti és szakértői bizottságokban; a jegybank egyik igazgatója, nemzetközi szervezetek és egyezmények létrehozásának fontos résztvevője és parlamenti képviselő is volt.

Az utóbbi pozíció mérsékelt formában mutatja a szerepváltások lehetőségét. Nemcsak a politikusok és a magáncégek között nincs mágikus vonal (ShleiferVishny, 1994, 998. o.) a befolyás vagy az egyik területről a másikba kerülés szempontjából, hanem a politika és a tudomány között sem.

A kommunista és szociáldemokrata mozgalmakban különösen gyakoriak voltak a szerepkeveredések és átlépések, amit a korai államosítási teóriák terepén főként orosz, német és svéd esetek példáznak. Lenin és Bernstein, Wigforss és Myrdal egyszerre - időben váltakozó hangsúlyokkal - volt pártjának teoretikusa és aktív politikusa. Ilyenkor a meggyőzés fontos része a párton belüli elfogadtatás, az agitatív újságcikkek mellett a politikai fórumokon elmondott beszédek, programjavaslatok kidolgozása. Többen kormányzati bizottságok vezetöjeként vagy tagjaként próbálták meg a gyakorlatba átültetni nézeteiket, mint Sydney Webb és Richard Tawney az I. világháború utáni angol államosítási testületekben.

Azt gondolhatnánk, hogy ebben a konstellációban az elmélet még közvetlenebbül befolyásolja a gyakorlatot. De az említett esetek tanulsága is az, hogy a politika rendre felülírja a teóriát. Az utóbbi igazodik az előbbihez, akár azon az áron is, hogy - mint Lenin - a politikussá vált tudós maga is revizionista lesz. Kautsky talán alapos okkal tiltakozott az ellen, hogy a teoretikusnak feladata hidat építeni az elmélet és a gyakorlat között - mert ez ,az elmélet halála” (idézi: Loppert, 2003, 37. o.).

Kérdéses, hogy a politikai térfélre átlépő tudós mennyiben tekinthető továbbra is az elmélet emberének. „Arra a következtetésre jutottam - és ezzel talán nem állok egyedül -, hogy ha egy közgazdász Washingtonba megy [kormányzati alkalmazottnak $-V$.É.], akkor már nem nagyobb a hitelessége, és nem is kevesebb, mint bármely más politikai kinevezetté, és kicsit megtévesztő doktornak vagy professzornak szólítani” - idézi George Stiglert Schliesser [2007, 31. o.].

A politikai pozíció vállalása, de már a közvetlen kormányzati tanácsadás is felveti a tudomány és a társadalmi változások viszonyának egy érzékeny, az értelmiség felelősségét érintő kérdését, amit az előbb hivatkozott Eric Schliesser [2007, 28. o.] így fogalmaz meg: ,...ha az elmélet a rendszerek kiépítésének alapja, akkor az elvi tervezés társadalommérnökséggé válik". Ez a társadalommérnökség különösen az 
egyéni szabadságra, szerves fejlődésre épülő liberális paradigmák esetében kényes pont - amelyek a társadalom, a gazdaság tervezését Hayek kifejezésével „végzetes önhittségnek" tartják -, és kiváltképpen akkor, ha gyakorlati megvalósítói elnyomó rendszerek (gyarmatosítók vagy diktátorok).

Az utóbbi eset mintapéldája Chile, ahol a magas kormányzati posztokba kinevezett közgazdászok, a neoliberális egyetemen végzett „chicagói fiúk” Friedman és a monetarizmus elvei alapján hozták létre Pinochet szabadpiaci berendezkedését. A sztárközgazdász személyes látogatást is tett a dél-amerikai országban, és a diktátorhoz írt levelében részletes tanácsokat adott az infláció megfékezésére egy rövid, de radikális „,sokkprogram” segítségével (Friedman-Friedman, 1998, 591-93. o.). Ezért sok támadás érte, többek között Stockholmban, a Nobeldíj átvételekor. Friedman azzal védekezett, hogy csak „technikai jellegű gazdasági tanácsokat” adott, a programot a chilei szakértők dolgozták ki. „Szerepünk csak annyi volt - írja -, hogy ellenőrizzük következtetéseiket, rányomjuk a jóváhagyó pecsétet, és segítsünk eladni a tervet a közvéleménynek és a katonai juntának" - ráadásul a szabad piac végül elvezetett a politikai szabadsághoz is (idézi: Schliesser, 2007, 32. o.).

A kétségek azonban, mint Schliesser tanulmánya is mutatja, tartósan fennmaradtak.

\section{A ,korrumpált tudomány”}

Hasonló aggályok általánosabban is megfogalmazhatók a közgazdaságtan etikai minőségével kapcsolatban. Ha modellezhető a ,jóindulatú” és „megvesztegethető,” azaz közérdeket, illetve önérdeket követő kormányzat, ${ }^{22}$ akkor miért ne alkalmazhatnánk a megkülönböztetést elemzésünk másik főszereplöjére is? George Yarrow esszéje [2014] ezt tette a korrumpált tudomány fogalmának bevezetésével. ${ }^{23}$

Az ilyen tudomány egyrészt leegyszerủsítő (nem feltétlenül módszertanilag, mert kifinomult analitikus modellként is megjelenthet): „...szisztematikusan figyelmen kívül hagy olyan tudást és információt, amely lényeges lenne a különböző gazdaságpolitikai döntések következményeinek értékeléséhez.” Másrészt „képtelen arra, hogy ellenálljon a parciális vagy magánérdekek illegitim befo-

${ }^{22}$ Lásd például: Shleifer-Vishny [1994], Shleifer [1998] kategorizálását a privatizáció célszerűségének modellezésekor.

${ }^{23}$ A „korrumpált” jelző nem feltétlenül pénzbeli megvesztegetés, hanem a szó eredeti, tágabb jelentésében kell értenünk: megrontott, tisztességtelen - bár mint látni fogjuk, egzisztenciális-anyagi érdekek is szerepet játszhatnak kialakulásában. 
lyásának, ...és hajlandó az elemzést ezeknek alárendelni.” Ezért „alkalmatlanná válik »hivatalos « céljának elérésére, az emberi magatartás következményeinek elemzésére és megértésére" (Yarrow, 2014, 3., 15., 33. o.). A szerző ezt alapvetően etikai hibának tekinti, amit a kereslet és a kínálat is táplál. A megrendelőként fellépő politikusoknak egyszerü, jól érthető és „eladható” történetekre (javaslatokra) van szükségük, ${ }^{24}$ amelyek az általuk fontosnak tartott érdekeket veszik figyelembe, a tudós-tanácsadó pedig pozíciójának, befolyásának megőrzése érdekében igyekszik ennek megfelelni, úgy, hogy „...a tanács valamilyen módon torzított lesz, mielött (és néha miután) azt megfogalmazták" (i. m. 4. o.). Így a javaslat - és a javaslattevő - megbízhatósága, erkölcsi fedezete elvész, a döntéshozók pedig segítségükkel elhárítják a felelősséget, voltaképpen visszaélnek hatalmukkal. Ez az alaphelyzet magát a tudományt, annak autonóm és pártatlan lényegét fenyegeti, ha - mint Yarrow állítja, legalábbis a közszervezetekre (public organizations) nézve - itt is érvényesül a Gresham-törvény: a korrumpált érvelés kiszorítja a megalapozottabb, körültekintőbb közgazdasági okfejtéseket. Akkor bekövetkezhet, amit Mises az 1920-as években keserűen és nyilván karikírozva írt, a német történeti iskolát és az amerikai (régi) intézményi közgazdaságtant mint a „harmadik út” képviselőit bírálva: „Aki a szabályozott magántulajdon harmadik társadalmi rendjét ajánlja, kereken tagadja a tudományos ismeretek lehetőségét a közgazdaságtanban... A közgazdaságtant hivatalosan eltörölték, betiltották, állami és rendőrségi tudománnyal helyettesítették, amely regisztrálja a kormány rendelkezéseit és javaslatokat tesz újabb rendeletekre" (Mises, 1929/1976, 18. o.).

Nyilvánvaló, hogy az elromlás veszélye nagyobb akkor, amikor a szakma szerepe nem az irányadás, hanem a legitimálás. Talán azt is mondhatjuk, hogy az utóbbi eset - még akkor is, amikor képviselőjének személyes meggyőződése egybeesik az általa igazolt tudományos vagy gazdaságpolitikai iránnyal - korrumpált tudományt jelent abban az értelemben, hogy az elveszti alapvetö funkcióit, az elfogulatlan elemzést, a megértést és értelmezést. $\mathrm{S}$ ami még rosszabb, ez nemcsak a domináns, hanem az éppen ellenzékbe szorult nézetrendszerekre is áll. Az államosítási és privatizációs hullámok is sok példát adnak arra, hogy az utóvédharcok vagy az „életben tartott”, a szélre szorított tanszékeken, periférikus folyóiratok köreiben meghúzódó régi elméletek ugyanolyan dogmatikusak és részrehajlók, mint az újak.

${ }^{24}$ Ennek szélsőséges formája az Igen, miniszterelnök úr címü tévésorozatnak a szerző által is felidézett sémája: „Valamit tennünk kell. Ez valami. Úgyhogy ezt kell tennünk.” 
A kisebbségi helyzet nem jelent feltétlenül etikai fölényt. A tudományos következményei nem, legfeljebb a társadalmi hatásai kevésbé visszatetszők - bár ez sem kevés.

\section{Siker vagy kudarc?}

Mit jelent tehát a teória akár megrontott, akár nem korrumpált változatának sikere és mik a siker feltételei? Az első kérdésre egyszerủ a válasz: a tudományos elfogadottság és a gazdaságpolitikai alkalmazás, ha korlátozottan, a politikai szürő által módosítva is, de viszonylag hosszú időn át, kedvező következményekkel. Ez Keynesre és a monetarizmusra is igaz, ami rávetült a hozzájuk kapcsolódó államosítási és privatizációs elméletekre. Az utóbbiak szintén sikert arattak a maguk idejében. Befolyásolták a gazdaságpolitikát, de szerepük a 20. század második harmadától kezdve nem annyira az irányok kijelölése, mint inkább az utólagos legitimálás lett: igazolást és hivatkozási alapot adtak a tölük többé-kevésbé függetlenül kialakított kormányzati döntéseknek, majd a kuhni értelemben vett „,normál tudomány” aprómunkájának keretében további alátámasztást nyújtottak azok folyamatos érvényesítéséhez.

Általánosságban nézve a tudományos elfogadtatás esélyét javítja, ha az új rendszer átfogó, de egyszerủ (persze a szónak inkább az elegáns, mint a szimplifikáló értelmében), néhány kulcselemre összpontosít, nem érvényteleníti teljesen a régi fogalmakat és technikákat, hanem sokat közülük magába olvaszt. A politikai elfogadást pedig segíti a társadalmi-gazdasági válság keltette bizonytalanság, az igény az új magyarázatra és az éppen legfontosabbnak ítélt bajok orvoslására, továbbá az, ha az elmélet megfelel az erős érdekcsoportok törekvéseinek és a közhangulatnak, a társadalom értékrendjének (vagy ezekkel összhangba hozható).

A tudományos és a politikai terepen is fontos az új elmélet megértetése és megismertetése a széles - szakmai vagy társadalmi - közvéleménnyel. Az elöbbi szférában alapvető jelentőségű az intézményépítés, beleértve az oktatás, a kutatás és a publikálás intézményeinek elfoglalását vagy újak létrehozását. A politikai kereslet kielégítése ezt is megalapozhatja, miközben egyfelöl lehetőséget teremt a tanácsadói, sőt politikai szerepek betöltésére, másfelől tágítja az elfogadtatás és befolyás lehetőségeit.

Csakhogy a siker elérésére alkalmazott módszerek, a hozzá vezető út és maga a siker korrumpálhat, megronthat. Amikor a tudomány átlép a politika térfelére és a 
hatásgyakorlás érdekében elfogadja magára nézve annak játékszabályait, akkor nagy a veszélye annak, hogy feladja saját értékeit, eredeti társadalmi funkcióját.

\section{Hivatkozások}

Bohle, D. - Greskovits, B. [2012]: Capitalist Diversity on Europe's Periphery. Cornell University Press, New York.

Campbell, J. L. [1997]: Institutional Analysis And The Role Of Ideas In Political Economy. Letölthetö: www.researchgate.net/profile/John_Campbell29/publication/226536145_Institutional_Analysis and_Role_of_Ideas_in_Political_Economy/links/0c96052e9563c0ff95000000/InstitutionalAnalysis-and-Role-of-Ideas-in-Political-Economy.pdf

Carlson, B. - Jonung, L. [2006]: Knut Wicksell, Gustav Cassel, Eli Heckscher, Bertil Ohlin and Gunnar Myrdal on the Role of the Economist in Public Debate. Econ Journal Watch, Vol. 3., No. 3., 511-550. o.

Colander, D. - Holt, R. - Rosser, B. [2004]: The Changing Face of Mainstream Economics. Review of Political Economy, Vol. 16., issue 4., 485-499. o.

Csaba László [1995]: A nemzetközi pénzügyi szervezetek és a kelet-európai rendszerátalakító politika. Közgazdasági Szemle, XLII. évf., 2. sz., 117-138. o.

Csaba László [1999]: A rendszerváltozás elmélete és/vagy a közgazdaságtan kudarca? Közgazdasági Szemle, XLVI. évf., 1. sz., 1-19. o.

Csaba László [2014]: Európai közgazdaságtan. Akadémia Kiadó, Budapest.

Farrell, H. - Quiggin, J. [2012]: Consensus, Dissensus and Economic Ideas: The Rise and Fall of Keynesianism During the Economic Crisis. Working Paper. Letölthetö: http:/www.henryfarrell. net/Keynes.pdf.

Freedman, C. [2006]: Not for Love Nor Money: Milton Friedman's Counter-Revolution. History of Economics Review, No. 44., 87-119. o.

Friedman, M. [1962/2002]: Capitalism and Freedom. The University of Chicago Press, Chicago, London.

Friedman, M. - Friedman, R. [1998]: Two Lucky People: Memoirs By Milton Friedman, Rose D. Friedman. Appendix A, 591-593. o. Letter from Friedman to Pinoche, April 21, 1975, The University of Chicago Press, London.

Galbraith, J. [2008]: The Collapse of Monetarism and the Irrelevance of the New Monetary Consensus. Policy Note, 2008/1. The Levy Institute of Bard College, New York.

Galbraith, J. K. [1988]: Egy kortárs emlékei. Európa Kiadó, Budapest.

Hall, P. A. (ed.) [1989a]: The Political Power of Economic Ideas. Keynesianism across Nations. Princeton University Press, Princeton, New Yersey.

Hall, P. A. [1989b]: Conclusion: The Politics of Keynesian Ideas. In: Hall, P. A. (ed.): 361-391. o.

Hall, P. A. [1993]: Policy Paradigms, Social Learning, and the State: The Case of Economic

Policymaking in Britain. Comparative Politics, Vol. 25., No. 3., 275-296. o.

Hayek, F. A. [1995]: Piac és szabadság. Válogatott tanulmányok, KJK, Budapest.

Kahneman, D. [2013]: A gyors és lassú gondolkodás. HVG Kiadó, Budapest.

Keynes, J. M. [1936/1965]: A foglalkoztatás, a kamat és a pénz általános elmélete. KJK, Budapest.

Konzelmann, S. [2011]: Anglo-Saxon Capitalism in Crisis? Models of Liberal Capitalism and the Preconditions for Financial Stability. Centre for Business Research, University of Cambridge, Working Paper, No. 422.

Kuhn. T. [1962/2000]: A tudományos forradalmak szerkezete. Osiris Kiadó, Budapest. 
Loppert Csaba [2003]: Sikerek és kudarcok az európai szociáldemokrácia történetében. Századvég Kiadó, Budapest.

Mises, L. von [1929/1976]: A Critique of Interventionism. Ludwig von Mises Institute, Auburn, Alabama.

Nasar, S. [2011]: The Grand Persuit. Simon and Schuster, New York.

Nelson, E. [2009]: Milton Friedman and U.K. Economic Policy: 1938-1979. Federal Reserve Bank of St. Louis Review, September/October 2009, 91 [5, Part 2]., 465-506. o.

Posner, R. A. [2009]: How I Became a Keynesian. New Republic, szeptember 23.

Schlett István [2017]: Appendix a politikai gondolkodás történetéhez. Kézirat.

Schliesser, E. [2007]: Friedman, Positive Economics, and the Chicago Boys. Letölthetö: https://ssrn. com/abstract $=1142741$ or http://dx.doi.org/10.2139/ssrn.1142741

Shleifer, A. [1998]: State versus private ownership. NBER Working Paper series, 6665.

Shleifer, A. - Vishny, R. [1994]: Politicians and Firms. The Quarterly Journal of Economics, Vol. 109., No. 4., 995-1025. o.

Skidelsky, R. [2009]: The Return of the Master, Allen Lane, London.

Voszka Éva [2015]: Államosítás, privatizáció és gazdaságpolitika - a föirány széttöredezés. Közgazdasági Szemle, LXII. évf., 7-8. sz., 717-748. o.

Voszka Éva [2017]: Államosítás, privatizáció - gazdaságtörténeti és tudománytörténeti nézöpontok. Kézirat.

Yarrow, G. [2014]: Dysfunctions in economic policymaking Part I: simple stories, complex systems and corrupted economics. Regulatory Policy Institute, Essays in Regulation, New Series, 4.1. 